\title{
OPTIMALISASI PELAYANAN PENGGUNAAN RUANG SIDANG DENGAN MEDIA ONLINE BERBASIS TEKNOLOGI INFORMASI DI LINGKUNGAN DIREKTORAT JENDERAL GURU DAN TENAGA KEPENDIDIKAN KEMENTERIAN PENDIDIKAN DAN KEBUDAYAAN
}

\author{
Samto $^{1}$, Adman $^{2}$ \\ samtobritish@yahoo.com; adman@upi.edu
}

\begin{abstract}
ABSTRAK
Optimalisasi pelayanan lembaga publik kepada masyarakat merupakan kewajiban yang harus selalu ditingkatkan. Optimalisasi pelayanan kepada masyarakat dan stakeholder menjadi dambaan bagi pengelola lembaga. Optimalisasi pelayanan adalah sebuah upaya untuk selalu meningkatkan dan memperbaiki kualitas dan kuantitas pelayanan dengan melibatkan komponen-komponen yang saling berkaitan satu sama lain. Optimalisasi pelayanan dapat ditempuh dengan berbagai cara, baik tradisional, maupun modern. Seiring dengan perkembangan zaman bentuk-bentuk pelayanan pada lembaga pemerintahan telah berubah bentuk dan orientasinya, dari cara-cara tradisional kearah modern dengan mempergunakan alat-alat atau media elektronik. Penggunaan media elektronik telah berkembang pesat seiring dengan kemajauan teknologi, informasi dan komunikasi. Penggunaan media elektronik dalam berbagai bidang telah membawa dampak kemudahan, kecepatan, transparansi dan akuntabilitas dan mampu meningkatkan pelayanan publik sehingga mampu mewujudkan good governance.
\end{abstract}

Kata Kunci: optimalisasi layanan, media online, teknologi informasi

Optimizing services of public institutions to the public is an obligation that must always be improved. Optimizing services to the community and stakeholders is a dream for the management of the institution. Service optimization is an effort to always improve and improve the quality and quantity of services by involving components that are interrelated with each other. Optimization of services can be reached in various ways, both traditional and modern. Along with the development of the times the forms of service in government institutions have changed their form and orientation, from traditional ways towards modernity using tools or electronic media. The use of electronic media has developed rapidly along with the advancement of technology, information and communication. The use of electronic media in various fields has brought the impact of ease, speed, transparency and accountability and is able to improve public services so as to be able to realize good governance.

Keywords : service optimization, online media, information technology

\section{PENDAHULUAN}

Optimalisasi pelayanan lembaga publik kepada masyarakat merupakan kewajiban yang harus selalu ditingkatkan. Optimalisasi pelayanan kepada masyarakat dan stakeholder menjadi dambaan bagi pengelola lembaga. Optimalisasi pelayanan adalah sebuah upaya untuk selalu meningkatkan dan memperbaiki kualitas dan kuantitas pelayanan dengan melibatkan komponen-komponen yang saling berkaitan satu sama lain. Optimalisasi pelayanan dapat ditempuh dengan berbagai cara, baik tradisional, maupun modern. Seiring dengan perkembangan zaman bentuk-bentuk pelayanan pada lembaga pemerintahan telah 
berubah bentuk dan orientasinya, dari cara-cara tradisional kearah modern dengan mempergunakan alat-alat atau media elektronik. Penggunaan media elektronik telah berkembang pesat seiring dengan kemajauan teknologi, informasi dan komunikasi. Penggunaan media elektronik dalam berbagai bidang telah membawa dampak kemudahan, kecepatan, transparansi dan akuntabilitas dan mampu meningkatkan pelayanan publik sehingga mampu mewujudkan good governance.

Merujuk UU No.25 tahun 2009 bahwa setiap instansi pemerintah harus meningkatkan pelayanan publik dengan berbagai upaya dan inovasi sesuai dengan peraturan perundangundangan. Inovasi yang dilakukan oleh penyelenggara layanan publik harus disesuaikan dengan situasi dan kondisi agar dapat memenuhi hasil yang optimal. Upaya peningkatan layanan publik yang berkaitan dengan penggunaan ruang sidang di lingkungan Direktorat Jenderal Guru dan Tenaga Kependidikan terus dilakukan. Saat ini masih ditemukan permasalahan manyangkut penggunaan ruang sidang, seperti ketidakteraturan dalam permintaan layanan. Oleh karena itu, perlu upaya serius untuk mengatasi hal tersebut. Seiring dengan kemajuan teknologi, infomasi, dan komunikasi, bentuk pelayanan terhadap pengguna ruang sidang harus ditingkatkan. Salah satu bentuk upayanya adalah memanfaatkan teknologi informasi berbasis jaringan (WEB). Namun, pemanfaatan teknologi infomasi berbasis web harus mengikuti peraturan tentang keterbukaan informasi publik seperti yang diatur dalam undang-undang.

Untuk menunjang kondisi tersebut dan mendukung program E-Government Subbagian Rumah Tangga Bagian Umum dan Kepegawaian membuat aplikasi layanan yang berbasis jaringan (WEB) dengan menggunakan Internet dan Intranet dalam layanan penggunaan ruang sidang di lingkungan Direktorat Jenderal Guru dan Tenaga Kependidikan.

Dalam melaksanakan tugasnya, Kepala Sub Bagian Rumah Tangga Bagian Umum dan Kepegawaian berpedoman pada Visi, Misi, dan Tujuan Direktorat Jenderal Guru dan Tenaga Kependidikan Kemendikbud

Visi Ditjen Guru dan Tenaga Kependidikan Tahun 2015-2019 mengacu pada rumusan visi Kemendikbud yaitu: "Terbentuknya Insan serta Ekosistem Pendidikan dan Kebudayaan yang Berkarakter dengan Berlandaskan Gotong Royong”.

Dalam rangka mewujudkan Visi Kemdikbud tersebut, Ditjen Guru dan Tenaga Kependidikan menetapkan misi sebagai berikut:

1) Mewujudkan Guru dan Tenaga Kependidikan yang Berkinerja Baik,

2) Mewujudkan Guru dan Tenaga Kependidikan yang Profesional dan Sejahtera

3) Mewujudkan Penataan dan Distribusi Guru dan Tenaga Kependidikan yang Meluas, Merata, dan

Berkeadilan,

4) Mewujudkan Peningkatan Tata Kelola serta Peningkatan Efektivitas Birokrasi Ditjen Guru dan

Tenaga Kependidikan dan Pelibatan Publik.

Tujuan strategis Ditjen Guru dan Tenaga Kependidikan yang ingin dicapai dalam periode waktu 2015 -2019, mengacu pada tujuan strategis Kemendikbud yaitu:

1) Penguatan Peran Guru dan Tenaga Kependidikan dalam Ekosistem Pendidikan

2) Peningkatan Profesionalisme Guru dan Tenaga Kependidikan untuk Mewujudkan Pembelajaran yang Bermutu

3) Peningkatan Penataan dan Distribusi Guru dan Tenaga Kependidikan yang Meluas, Merata dan Berkeadilan;

Sebagai penjabaran dari rencana strategis Ditjen Guru dan Tenaga Kependidikan Kementerian Pendidikandan Kebudayaan serta sesuai dengan Permendikbud Nomor 11 Tahun 2015 tentang Organisasi dan Tata Kerja Kementerian Pendidikan dan Kebudayaan, bahwa Sub Bagian Rumah Tangga Bagian Umum dan Kepegawaian merupakan salah satu dari tiga Satuan Kerja Eselon empat di lingkungan Bagian Umum dan Kepegawaian 
Setditjen Guru dan Tenaga Kependidikan. Secara organisasi, kedudukan herarki Sub Bagian Rumah Tangga di lingkungan Setditjen Guru dan Tenaga Kependidikan seperti dalam struktur organisasi sebagai berikut.

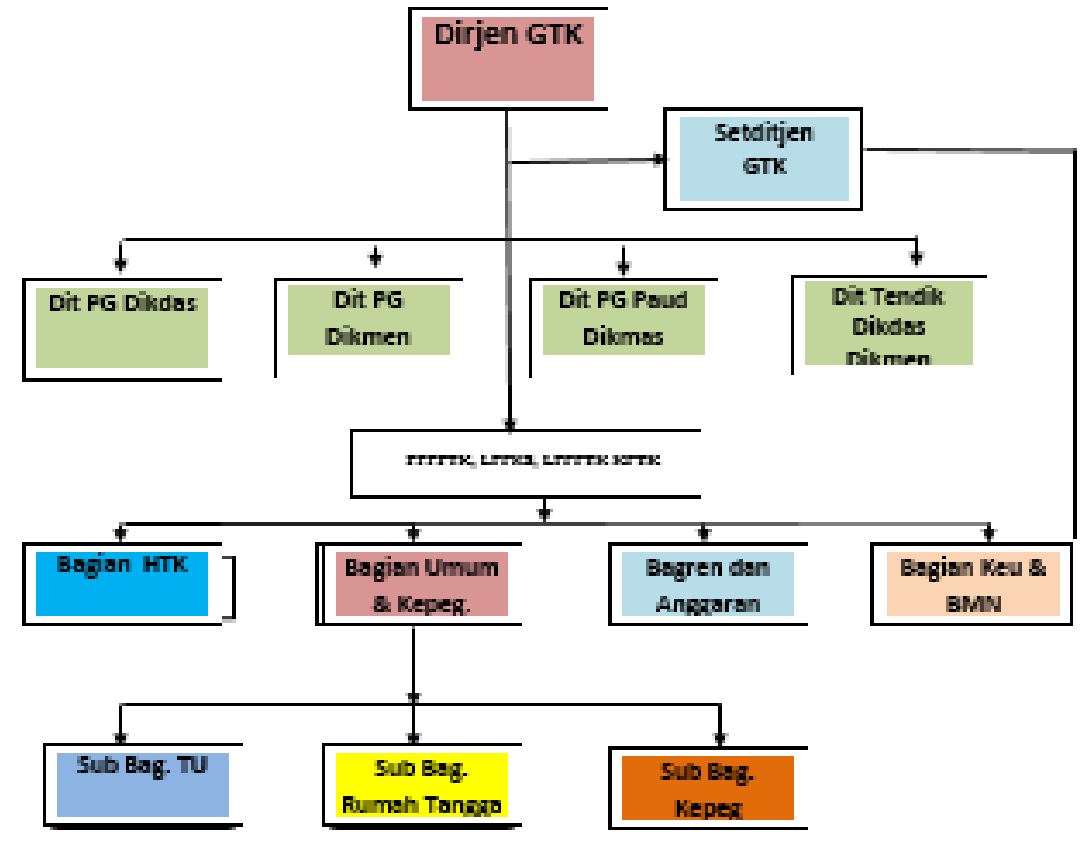

Gambar 1.

Struktur Organisasi Direktorat Jenderal Guru dan Tednaga Kependidikan

Pasal 145 (2) Permendikbud Nomor 11 Tahun 2015 menyatakan bahwa Sub Bagian Rumah Tangga Bagian Umum dan Kepegawaian Setditjen Guru dan Tenaga Kependidikan mempunyai tugas melakukan urusan keprotokolan, keamanan, kebersihan, keindahan, pemeliharaan sarana prasarana, pengaturan penggunaan sarana dan prasarana, dan kendaraan dinas, serta poliklinik di lingkungan Direktorat Jenderal Guru dan Tenaga Kependidikan Salah satu tugas Sub Bagian Rumah Tangga dalam bidang pengaturan penggunaan sarana prasarana adalah melakukan layanan penggunaan ruang sidang di lingkungan Ditjen Guru dan Tenaga Kependidikan.

\section{PEMBAHASAN}

Pelaksanaan Tiap Tahapan Kegiatan Penjelasam Pelaksanaan Proyek Perubahan Setiap Milestone

\section{Persiapan Perencanaan Proyek Perubahan}

Pada tahap persiapan terdapat dua kegiatan yaitu 1). Konsultasi dengan Mentor tentang jadwal kegiatan proyek perubahan dan 2). Konsultasi dengan Mentor terkait dengan rancangan anggaran belanja (RAB) proyek perubahan. Tahapan ini dijelaskan dalam uraian berikut ini:

\section{a. Konsultasi dengan Mentor}

Konsultasi dengan Mentor tentang jadwal kegiatan proyek perubahan dilaksanakan pada tanggal 21 September 2016. Konsultasi dimaksudkan adalah konsultasi antara tim leader projek kepada mentor dalam hal ini Kabag Umum dan Kepegawaian. Kegiatan betempat di ruang Kepala Bagian Umum dan Kepegawaian. Output kegiatan konsultasi adalah tersusunnya jadwal kegiatan proyek perubahan di lingkungan Ditjen GTK. Selanjutnya jadwal tersebut dikonsultasikan kepada pembimbing pada tanggal 24 September 2016. 


\section{b. Konsultasi dengan Mentor terkait dengan rancangan anggaran belanja (RAB) proyek perubahan}

Langkah persiapan yang kedua adalah Konsultasi dengan Mentor terkait dengan rancangan anggaran belanja $(\mathrm{RAB})$ proyek perubahan. Kegiatan ini adalah konsultasi antara projek leader dengan mentor untuk membahas dan menentukan pembiayaan proyek perubahan. Kegiatan dilaksanakan pada tanggal 21 September 2016 bertempat di ruang kerja Kabag Umum dan Kepegawaian. Output kegiatan ini adalah rancangann anggaran biaya $(\mathrm{RAB})$ proyek perubahan . Selanjutnya hasil kegiatan Konsultasi dengan Mentor terkait dengan rancangan anggaran belanja (RAB) proyek perubahan dilaporkan kepada pembimbing pada tanggal 26 September 2016.

\section{Pengorganisasian}

Tahapan berikutnya adalah penggorganisasian. Pengorganisasian pada hakekatnya adalah proses untuk menyusun personalia yang terlibat dalam proyek perubahan. Personalia tersebut akan tergabung dalam tim efektif. Ada dua langkah yang dilakukan dalam tahapn ini yaitu 1). Membangun komitmen terhadap proyek perubahan. 2). Pembentukan tim efektif.

\section{a. Membangun Komitmen}

Langkah membangun komitmen dalam proyek perubahan adalah langkah untuk menyamakan persepsi terhadap semua komponen yang terlibat dalam proyek perubahan ini. Kegiatan berlangsung pada tanggal 21 September 2016, bertempat di ruang kerja Kabag Umum dan Kepegawaian. Output kegiatan ini adalah Pernyataan dukungan terhadap proyek perubahan dari pimpinan mengenai proyek perubahan ini. Hasil kegiatan dilaporkan pada pembimbing pada tanggal 26 September 2016.

\section{b. Pembentukan Tim}

Rapat Pembetukan Tim telah dilaksanakan pada tanggal 22 September 2016.

Langkah ini dilakukan dalam rangka membentuk tim efektif yang akan bekerja sebagai pelaksana dan penggerak proyek perubahan. Kegiatan berlangsung di ruang rapat Bagian umum dan Kepegawaian Setditjen GTK. Output kegiatan adalah Surat Keputusan Tim efektif dan rincian tugas masing-masing anggota tim. Hasil kegiatan selanjutnya dilaporkan pada pembimbing pada tanggal 26 September 2016.

\section{Koordinasi}

Tahapan koordinasi adalah kegiatan penjelasan tentang jadwal kegiatan dan rindcian tugas masing-masing anggota tim efktif. Kegiatan berlangsung pada tanggal 22 september 2016. Kegiatan bertempat di Ruang Rapat VIP II gedung D lantai 11 Kemdikbud. Output kegiatan adalah ketetapan jadwal proyek perubahan dan ketetapan rincian tugas pada setiap anggota tim efektif. Selanjutnya hasil kegiatan dilaporkan pada pembimbing proyek perubahan pada tanggal 26 September 2016.

\section{Tahapan Pelaksanaan}

Tahapan pelaksanaan proyek perubahan terdiri dari 1). Rapat persiapan penyusunan Prosedur Operasional Standar, 2). Penyusunan Prosedur Operasional Standar. 3). RDK Standar Layanan Penggunaan Ruang Sidang, 4). RDK Persiapan Penyusunan Prototype Aplikasi Layanan Penggunaan Ruang Sidang, 5). Uji Coba Aplikasi Layanan Penggunaan Ruang Sidang, 6). Penyempurnaan Aplikasi Layanan Penggunaan Ruang Sidang 7). Penyusunan Modul Aplikasi Layanan Penggunaan Ruang Sidang.

\section{Tahapan Evaluasi}

Terdapat tiga kegiatan dalam tahap evaluasi, kegiatan evaluasi dilaksanakan di Lantai 16 Gedung D Setditjen GTK. Pelaksanaan masing-masing kegiatan tersebut dapat dijelaskan sebagai berikut. 

a. Menyiapkan Instrumen Evaluasi (Kuesioer)
b. Melakukan Evaluasi Tahapan Kegiatan Proyek Perubahan dengan Instrumen
c. Menganalisis Hasil Evaluasi

Tabel 1

Hasil Visibilitas Sistem Persi-Elektronik

\begin{tabular}{|c|c|c|c|c|c|}
\hline \multirow{2}{*}{ No } & \multirow{2}{*}{ Indikator } & \multicolumn{4}{|c|}{ Penilaian } \\
\hline & & SB & B & CB & $\mathrm{Br}$ \\
\hline 1 & $\begin{array}{l}\text { Visibility of system status. (Visibilitas } \\
\text { status sistem informasi) }\end{array}$ & $21 \%$ & $46 \%$ & $21 \%$ & $13 \%$ \\
\hline 2 & $\begin{array}{l}\text { Match between system \& the real world. } \\
\text { (Kesesuaian antara sistem \& dunia nyata) }\end{array}$ & $29 \%$ & $50 \%$ & $17 \%$ & $4 \%$ \\
\hline 3 & $\begin{array}{l}\text { User control and freedom. (Kontrol dan } \\
\text { Kebe basan Pengguna) }\end{array}$ & $21 \%$ & $42 \%$ & $21 \%$ & $17 \%$ \\
\hline 4 & $\begin{array}{l}\text { Consistency and standards. (Standard dan } \\
\text { Konsistensi) }\end{array}$ & $25 \%$ & $46 \%$ & $21 \%$ & $8 \%$ \\
\hline 5 & $\begin{array}{l}\text { Error prevention. (Pencegahan } \\
\text { Kesalahan) }\end{array}$ & $25 \%$ & $50 \%$ & $13 \%$ & $13 \%$ \\
\hline 6 & $\begin{array}{l}\text { Recognition rather than recall. } \\
\text { (Mengenali bukan Mengingat) }\end{array}$ & $17 \%$ & $50 \%$ & $21 \%$ & $13 \%$ \\
\hline 7 & $\begin{array}{l}\text { Flexibility and efficiency of use. } \\
\text { (Fleksibilitas dan Efisiensi Penggunaan) }\end{array}$ & $13 \%$ & $63 \%$ & $17 \%$ & $8 \%$ \\
\hline 8 & $\begin{array}{l}\text { Aesthetic and minimalist design. (Estetika } \\
\& \text { desain yang minimalis) }\end{array}$ & $21 \%$ & $46 \%$ & $21 \%$ & $13 \%$ \\
\hline 9 & $\begin{array}{l}\text { Help users recognize, diagnose, and } \\
\text { recover from errors. (Membantu } \\
\text { pengguna untuk mengenali, mendiagnosa, } \\
\text { memulihkan dari kesalahan) }\end{array}$ & $21 \%$ & $67 \%$ & $8 \%$ & $4 \%$ \\
\hline 10 & $\begin{array}{l}\text { Help and documentation. (Bantuan dan } \\
\text { dokumentasi) }\end{array}$ & $8 \%$ & $67 \%$ & $17 \%$ & $8 \%$ \\
\hline & JUMLAH & $20 \%$ & $53 \%$ & $18 \%$ & $10 \%$ \\
\hline
\end{tabular}

\section{Tahapan Pelaporan Proyek Perubahan}

Pelaporan proyek perubahan terbagi menjadi tiga kegiatan yaitu pengumpulan dokumen bukti fisik, penyusunan laporan proyek perubahan dan pembuatan paparan (power point) untuk seminar laboratorium proyek perubahan (LPP) yang dilaksanakan pada tanggal 1116 November 2016. Kegiatan tersebut berlangsung di Lantai 16 Gedung D Setditjen GTK.
a. Pengumpulan dokumen bukti fisik
b. Penyusunan laporan proyek perubahan
c. Pembuatan paparan (power point) untuk seminar laboratorium proyek perubahan (LPP)

\section{Tahapan Evaluasi \\ Analisis Data}

Pengumpulan data efektivitas penggunaan Sistem Pelayanan Penggunaan Ruang Sidang Elektronik dilakukan menggunakan kuesioner. Koesioner diberikan kepada responden pada saat Bimbingan teknis, yaitu dengan cara memerintahkan peserta sebagai responden untuk mengisi kuesioner sesuai dengan kondisinya, setelah mereka mengikuti bimbingan teknis implementasi Aplikasi Persi-E. Selanjutnya hasil angket tersebut di oleh 
menggunakan perhitungan statistik sederhana, sehingga hasilnya dapat dijelaskan dan dianalisis untuk melihat keberadaan Aplikasi Persi-E.

\section{Pelaporan Hasil Evaluasi}

Selanjutnya evaluasi juga memotret tentang kelayakan pengembangan sistem aplikasi. Kelayakan sistem aplikasi dinilai dan dievaluasi menggunakan analisa sederhana. Metode analisa merujuk pada model analisa diungkap oleh Ida Ayu Putu Ari Krisnayanti(Ayu \& Ari, 2014) Instrumen analisa diambil dari indikator sebagai berikut ; Kecepatan, Ketepatan, Keamanan, Manfaat sistem, Dampak sistem. Stakeholders memberikan persepsi tentang penerapan Arsip-E dengan memberikan skor penilaian pada kategori : Sangat Baik, Baik, Cukup dan Buruk.

Tabel 2

Gambaran Variabel

\begin{tabular}{|c|c|c|c|c|c|c|c|}
\hline \multirow[t]{2}{*}{ Skor } & \multicolumn{5}{|c|}{ Indikator } & \multirow{2}{*}{$\begin{array}{c}\text { Frekue } \\
\text { nsi }\end{array}$} & \multirow{2}{*}{$\begin{array}{l}\text { Persent } \\
\text { ase }\end{array}$} \\
\hline & $\begin{array}{c}\text { Kecepa } \\
\tan \end{array}$ & $\begin{array}{c}\text { Ketepa } \\
\tan \end{array}$ & $\begin{array}{c}\text { Keama } \\
\text { nan }\end{array}$ & $\begin{array}{l}\text { Manfaat } \\
\text { Sistem }\end{array}$ & $\begin{array}{c}\text { Dampak } \\
\text { Sistem }\end{array}$ & & \\
\hline \multirow[t]{2}{*}{ BK } & 1 & 2 & 4 & 3 & 3 & \multirow[t]{2}{*}{13} & \multirow[t]{2}{*}{$9 \%$} \\
\hline & $3 \%$ & $7 \%$ & $13 \%$ & $10 \%$ & $10 \%$ & & \\
\hline \multirow[t]{2}{*}{$\mathrm{C}$} & 5 & 6 & 11 & 5 & 3 & \multirow[t]{2}{*}{30} & \multirow[t]{2}{*}{$20 \%$} \\
\hline & $17 \%$ & $20 \%$ & $37 \%$ & $17 \%$ & $10 \%$ & & \\
\hline \multirow[t]{2}{*}{ B } & 18 & 15 & 9 & 15 & 16 & \multirow[t]{2}{*}{73} & \multirow[t]{2}{*}{$49 \%$} \\
\hline & $60 \%$ & $50 \%$ & $30 \%$ & $50 \%$ & $53 \%$ & & \\
\hline \multirow[t]{2}{*}{ SB } & 6 & 7 & 6 & 7 & 8 & \multirow[t]{2}{*}{34} & \multirow[t]{2}{*}{$23 \%$} \\
\hline & $20 \%$ & $23 \%$ & $20 \%$ & $23 \%$ & $27 \%$ & & \\
\hline $\begin{array}{c}\text { Jumlah } \\
\text { Responden }\end{array}$ & 30 & 30 & 30 & 30 & 30 & 150 & $100 \%$ \\
\hline
\end{tabular}

\section{Tahapan Evaluasi}

Rangkuman pentahapan kegiatan dapat dilihat pada gambar berikut ini:

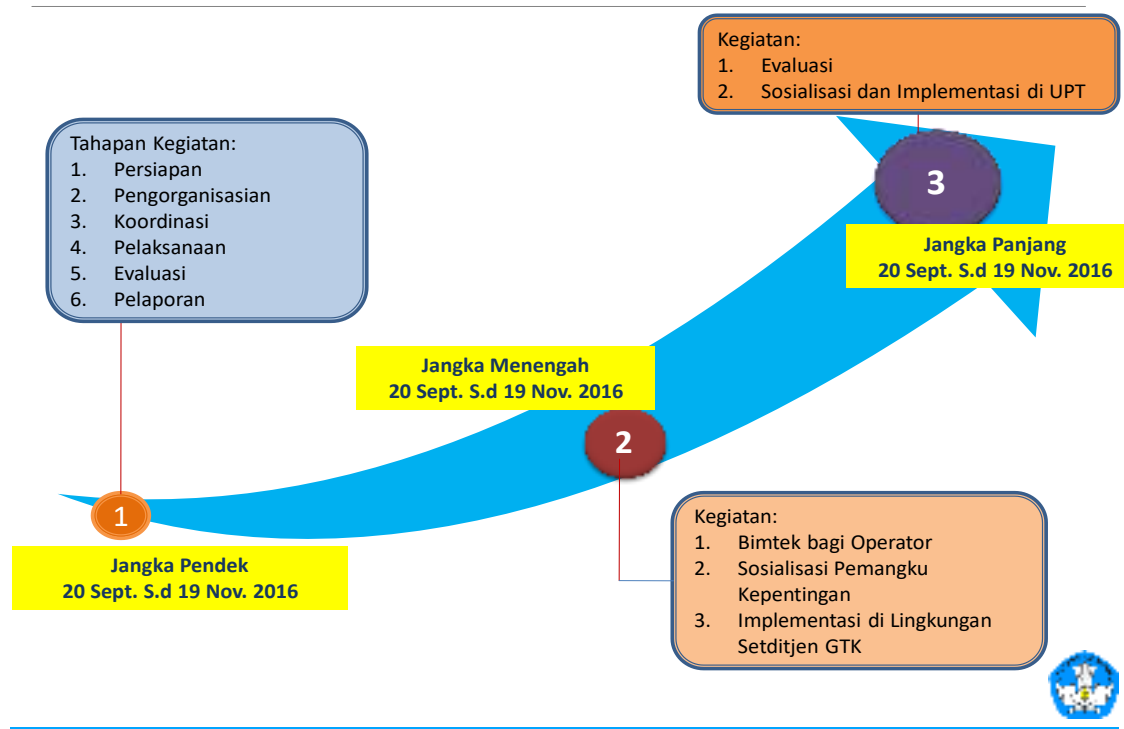

Gambar 2

Pentahapan Kegiatan Proyek Perubahan 


\section{Kendala}

Pelaksanaan suatu proyek pada umumnya mengalami dinamika yang beragam. Ada kalanya berjalan mulus tapi tidak jarang mengalami kendala. Istilah lain dari kendala adalah resiko, menurut pendapat ahli Definisi manajemen risiko adalah merupakan proses formal dimana faktor-faktor risiko secara sistematis diidentifikasi, dianalisis, respon, dan dikendalikan. Hal yang pasti pada setiap proyek adalah mengalami kendala. Kendalakendala dalam pelaksanaan suatu proyek tidak boleh dibiarkan begitu saja, melainkan harus di atasi dengan baik, sehingga sesuai dengan tujuan. Pada proyek perubahan ini juga terdapat kendala. Oleh karena itu perlu dilakukan satu analisa tentang kendala yang dihadapi dalam pelaksanaan proyek perubahan ini.

Untuk memberikan kemudahan maka analisa kendala harus memperhatikan metode atau pendekatan yang digunakan. Kendala-kendala sebuah proyek sering kali terjadi menurut (7) antara lain:

1. Metode pengoperasian alat tidak tepat

2. Melakukan perubahan terhadap disain

3. Keahlian yang tidak cukup untuk Perobahan desain spesifikasi

4. Menggunakan tenaga kerja yang tidak terampil

5. Material yang digunakan kurang dari yang dibutuhkan.

Kondisi di atas seringkali terjadi dalam sebuah proyek. Metode pengoperasian terhadap peralatan atau program yang digunakan tidak tepat atau tidak sesuai dengan kebutuhan riil. Hal ini akan mengakibatkan kendala yang sangat berati dalam pelaksanaan proyek perubahan. Melakukan perubahan terhadap disain juga menjadi kendala sebuah proyek. Pada hakekatnya sebuah proyek harus didahulu oleh sebuah perencanaan yang sangat matang. Apabila di tengah jalan ternyata mengalami perubahan desain maka secara otomatis akan merubah struktur program yang sudah terbentuk. Keahlian yang tidak cukup untuk perubahan spesifik juga akan menjadi kendala yang sangat berarti. Penggunaan tenaga kerja yang tidak terampil juga merupakan faktor kendala yang sangat berarti. Idealnya sebuah proyek sudah dengan persiapan tenaga kerja yang handal. Akan tetapi manakala terdapat tenaga kerja yang terbatas, tidak cakap, tidak terampil, maka hal ini akan menimbulkan kendala yang berarti. Dan juga apaila material yang digunakan kurang maka apabila hal ini tidak segera mendapat penanganan kondisi semacam ini akan timbul permasalahan dan kendala yang berarti.

Atau pada proses berjalannya proyek perubahan ada beberapa kendala antara lain sebagai berikut :

1. Banyaknya beban kerja rutin yang dikerjakan oleh staf yang bersamaan dalam menghadapi daya serap anggaran sehingga banyak nya staf yang keluar daerah pada pekerjaan lain.

2. Terbatas nya sumber daya yang tersedia. Jumlah pegawai pada satuan kerja tidak sebanding dengan beban kerja yang harus dijalani, mengakibatkan terhambatnyan beberapa pekerjaan pokok.

3. Sifat program substantif yang dikerjakan bukanlah bidang keseharian yang dialami, sehingga memerlukan waktu yang cukup lama untuk bisa memahami konteksnya.

4. Keterbatasan sumber dana yang memadai untuk terus mengembangkan program perubahan ini.

Belum adanya regulasi yang tegas dalam mengatur program-program yang sifatnya baru. 


\section{Strategi Mengatasi Kendala}

Adapun kendala atau hambatan tersebut harus dicarikan solusinya dalam pelaksanaan proyek perubahan dan harus disikapi serta dicari strateginya untuk dapat menimplementasikan proyek perubahan ini dapat berjalan dengan lancer sesuai dengan target yang telah ditentukan sesuai dengan perencanaan, Adapun strategi yang kami gunakan adalah sebagai berikut :

1. Diusahakan seringnya komuikasi dan koordinasi sesama staf secara persuasive;

2. Membuat jadwal khusus untuk focus mengerjakan proyek peruban diluar jam kerja;

3. Membuat Tim bayangan sebagai cadangan jika Tim yang sudah ada mengalami gangguan.

4. Banyaknya beban kerja rutin yang dikerjakan oleh staf yang bersamaan dalam menghadapi daya serap anggaran sehingga banyak nya staf yang keluar daerah pada pekerjaan lain, maka strategi yang diterapkan adalah dengan pembagian tugas dan penjadwalan secara teratur.

5. Terbatasnya sumber daya yang tersedia. Jumlah pegawai pada satuan kerja tidak sebanding dengan beban kerja yang harus dijalani, mengakibatkan terhambatnyan beberapa pekerjaan pokok strategi yang dilakukan dengan cara menentukan skala prioritas dan mengangkat tim teknis untuk menyelesaikan bagian pekerjaan.

6. Sifat program substantif yang dikerjakan bukanlah bidang keseharian yang dialami, sehingga memerlukan waktu yang cukup lama untuk bisa memahami konteksnya, strategi yang dilakukan adalah melalui pelatihan dan pemantapan bidang substantif yang masih kurang.

7. Keterbatasan sumber dana yang memadai untuk terus mengembangkan program perubahan ini, Strategi yang dilakukan adalah dengan merelokasikan anggaran yang tidak terserap.

Belum adanya regulasi yang tegas dalam mengatur program-program yang sifatnya baru, strateginya adalah membuat aturan dan membuat keputusan untuk menetapkan aturan-aturan yang diperlukan.

\section{Capaian Kegiatan}

Capaian kegiatan dari proyek perubahan berdasarkan tahapan kegiatan milestone yang dilaksanakan pada Tanggal 20 September 2016 s.d 19 November 2016. Target capaian kinerja proyek perubahan ini secara rinci dapat dilihat sebagai berikut:

1. Terjadi peningkatan pemahaman stakeholder/pemangku kepentingan terhadap pentingnya Aplikasi Peminjaman Ruang Sidang Elektronik (Persi-E) di lingkungan Direktorat Jenderal Guru dan Tenaga Kependidikan.

2. Peningkatan pemahaman stake holder atau pemangku kepentingan terhadap Aplikasi Peminjaman Ruang Sidang Elektronik (Persi-E) di lingkungan Direktorat Jenderal Guru dan Tenaga Kependidikan.

3. Terjadi peningkatan pemahaman pentingnya penggunaan Aplikasi Peminjaman Ruang Sidang Elektronik (Persi-E) di lingkungan Direktorat Jenderal Guru dan Tenaga Kependidikan.

4. Timbulnya kesadaran akan manfaat dan keguanaan teknologi informasi dan komunikasi dalam berbagai kepentingan untuk memberikan kemudahan dalam pemberian layanan kepada stakeholders.

5. Terwujudnya semangat E-Goverment sebagaimana telah dicanangkan oleh pemerintah.

6. Terwujudnya implementasi Reformasi Birokrasi di lingkungan Direktorat Jenderal Guru dan Tenaga Kependidikan. 
Target capaian proyek perubahan tentang kearsipan elektronik Arsip (Arsip-E) akan ditindaklanjuti dengan program-program kegiatan lainnya.

\section{KESIMPULAN}

Optimalisasi pelayanan penggunaan ruang sidang dengan media online berbasis teknologi informasi pada kenyataanya belum optimal, disebabkan oleh keterbatasan pada aspek SDM, sarana dan prasarana, kebijakan pimpinan instansi dan dampak perkembangan teknologi informasi dan komunikasi.

Tuntutan kemajuan dan perkembangan teknologi, informasi dan komunikasi menuntut pemenuhan solusi terhadap persoalan pengelolaan pelayanan penggunaan ruang siding dengan media online. Terobosan melalui inovasi dalam bidang teknologi informasi mendorong untuk menciptakan media untuk mengelola ruang sidang secara modern, yaitu mengadakan penggunaan ruang siding berbasis teknologi informasi. Pengembangan dan optimalisasi pelayanan penggunaan ruang siding dengan media online berbasis teknologi inforasi adalah salah satu tawaran solusi untuk mengatasi permasalahan dalam pengoptimalan penggunaan ruang siding dengan media online.

Berbagai analisis dilakukan untuk mencari solusi terhadap persoalan pengelolaan optimalisasi pelayanan penggunaan ruang sidang dengan media online berbasis teknologi informasi, dengan tujuan untuk menghasilkan satu sistem pengelolaan ruang siding berbasis teknologi informasi secara modern dengan pendekatan teknologi informasi dan komunikasi. Pengembangan optimalisasi pelayanan penggunaan ruang sidang dengan media online berbasis teknologi informasi adalah solusinya. Analisis dengan pendekatan konsep Levit telah memetakan skala prioritas pengembangan sistem online. Pendekatan model Derek telah menghasilkan analisis stakeholder dimana stakeholder internal dan eksternal memiliki dukungan yang sangat tinggi terhadap pengembangan ruang siding berbasis teknologi informasi. Evalusi Usability Heuristics dari Nielsen telah menghasilkan kelayakan dan visibilitas aplikasi yang dikembangkan. Analisis usability heuristic menyimpulkan bahwa pelayanan penggunaan ruang sidang dengan media online berbasis teknologi informasi memiliki visibilitas dengan kategori baik, artinya memiliki keterbacaan oleh pengguna dengan baik.

Secara umum proses pelaksanaan kegiatan proyek perubahan berjalan dengan baik, lancar dan sesuai dengan perencanaan. Hasil pelaksanaan antara lain:

1. Tersedianya pelayanan penggunaan ruang siding online menjamin tersedianya ketersediaan informasi yang autentik dan terpercaya sebagai alat bukti sah khususnya dibidang kepegawaian dan keuangan serta menjamin terwujudnya pengelolaan ruang siding dengan online yang handal dan pemanfaatnanya sesuai dengan ketentuan perundang undangan

2. Keberadaan pelayanan penggunaan ruang sidang dengan media online berbasis teknologi informasi ini maka akan terciptanya pegawai yang terampil dan profesional dalam pengelolaan kearsipan dan sangat membantu bagi fungsional tertentu.

3. Adanya system pelayanan penggunaan ruang sidang dengan media online berbasis teknologi informasi maka dengan mudahnya serta cepat dalam hal ini staf atau pimpinan melakukan pertemuan.

4. Tersedianya system pelayanan penggunaan ruang sidang dengan media online berbasis teknologi informasi dapat mendinamiskan penyelengagaraan pertemuan sidang di suatu unit kerja sebagai suatu system yang koprehensip dan terpadu

Tersedianya system pelayanan penggunaan ruang sidang dengan media online berbasis teknologi informasi dapat menjamin kemudahan dalam mengelola pemesanan ruang sidang yang bersifat online 


\section{DAFTAR PUSTAKA}

Buku Road Map Reformasi Birokrasi Kementerian Pendidikan dan Kebudayaan tahun 2015-2019;

Buku Program Kerja Reformasi Birokrasi Kementerian Pendidikan dan Kebudayaan Tahun 2016;

Buku Panduan penyelenggaraan Diklatpim IV angkatan 3 Pusdiklat Pegawai Kementerian Pendidikan dan Kebudayaan tahun 2016;

Buku Self Mastery Diklatpim IV Angkatan 3 Tahun 2016; Buku Tim Efektif Diklatpim IV Angkatan 3 Tahun 2016;

Buku Agenda Inovasi Diklatpim IV Angkatan 3 Tahun 2016; Buku Diagnosa Perubahan Organisasi Diklatpim IV Angkatan 3 Tahun 2016.

Rizki Febria Nurita, Sudarsono LE. Optimalisasi Layanan Transaksi Elektronik Goverment dalam Upaya Mewujudkan Pelayanan Publik yang baik pada Bidang Perizinan Kota Malang. 2006;1-19.

Undang Undang No. 25 tahun 2009, tentang Pelayanan Publik. 2009.

Undang Undang No. 14 tahun 2008 tentang Keterbukaan Informasi Publik. 2008.

Instruksi Presiden No 3 tahun 2003, tentang Kebijakan Strategi Nasional Pengmbangan E Goverment [Internet]. 2003. Available from: http://simkum.baliprov.go.id/uploads/INPRES_3_2003.doc\%5Cnhttp://dishut.jabar prov.go.id/data/menu/INPRES2003_003.pdf

Permendikbud No.22 tahun 2015 tentang Renstra Kemendikbud 2015-2019. 2015.

Permendikbud No. 11 tahun 2015, Tentang Organisasi dan Tata Kerja Kementerian Pendidikan dan Kebudayaan. 2015.

Ismael I. Keterlambatan proyek konstruksi gedung faktor Penyebab dan tindakan pencegahannya Oleh. Februari J Momentum. 2013;14(1):46-56. 